\title{
Aesthetic Troposes of Fetishism
}

\author{
Iuriy V. Sobolev* \\ Krasnoyarsk State Institute of Art \\ 22 Lenin Str., Krasnoyarsk, 660049, Russia
}

Received 10.10.2015, received in revised form 21.11.2015, accepted 14.12.2015

The paper deals with aesthetic troposes. Referring to the fundamental works dedicated to fetishism and aesthetics (A. Baumgarten, K. Marx, W. Benjamin, G. Schulze etc.), the author reveals the characteristic aesthetic nature of fetishism. Summarizing the various positions, the author also puts forward and substantiates the hypothesis about the aesthetic protonature of fetishism.

Keywords: fetishism, aesthetics, aesthesis, aestheticization, religious phenomenon, alpha-strat, betastrat.

DOI: 10.17516/1997-1370-2016-9-1-133-139.

Research area: culture studies.

\section{Introduction}

The dynamics of polymorphic and drastic processes of the modern world has largely influenced the consolidation of the modulated representations about a number of cultural phenomena in the minds of laymen. One of these phenomena is fetishism. After hearing the word "fetishism", a researcher of the world of religious culture associates it with a definition that can be found in almost any book or training manual on religious studies. And there will not be a fundamental difference in the possible variation of the definition, as its basic semantic content is surprisingly limited with a traditional repeatability of a once found easy cliché. However, the sphere of religious studies is not the only one, where fetishism is researched. Psychology scientists refer to it more often, and, in addition, the palette of a psychological study of fetishism is more diverse. Finally, another area where fetishism is to be included in the problem field of research is aesthetics. However, the degree of aesthetic investigation of the problem is so insignificant that at the moment it would be fairer to talk about the philosophical and aesthetic reflection of fetishism in its private art aspects.

\section{Statement of the problem}

The philosophical understanding of fetishism was most publicized due to Karl Marx and his theory of fetishism of commodities. It is to be recalled that, the German philosopher put forward the idea that capitalist wealth was inevitably expressed in the form of commodity. The essence of Marx's fetishism of commodities is that the irrational power of public relations appears outwardly as the domination of certain things over people. This creates a mystical attitude of man to

(C) Siberian Federal University. All rights reserved

* Corresponding author E-mail address: ysob@mail.ru 
commodity as a supernatural power, veiling the dependence of producers on the market. Marx addressed to "fetishism" not accidentally and not episodically. It is known that the German thinker studied the treatises of Ch. de Boss and K. Meiners. The appearance of the definition of "fetishism of commodities" is associated with a fairly good knowledge of the studied problem field, and the definition of fetishism proposed by Marx, in our opinion, is one of the most accurate and concise: "Fetishism is very far from being able to raise man above his sensuous desires - on the contrary, it is a "religion of sensuous lusts" (the article of Marx in a German newspaper of 1842). The German philosopher's definition of fetishism as "the religion of sensuous lusts" highlights another facet of this phenomenon that is an aesthetic facet.

In the XVIIIcentury A. Baumgarten, who was a follower of Wolf, made an attempt (a successful attempt, which did not get enough attention and development) to create a scientific program that could allow aesthetics to dissociate itself from art claims and to become an independent, fullfledged division of philosophical knowledge. Baumgarten gave a name for the discipline "Aesthetica», offering to understand it as "the science of sensuous knowledge» [Baumgarten, 1883: 452]. "Sensuous" ("Sensually perceived signs of the sensuous") in this case should be understood not so much in a sensationalist way (as a feeling), but in a sensuous-emotional way (as phantasm) (A. Losev insists on the translation of «aestetica» exactly as "emotions").

This "uncertainty" in the fundamental positions of aesthetics is not accidental, and the difficulties which every thoughtful scholar faces, are expressed in the ambiguity of the substantive part of the object, which, in turn, is caused by the lack of an established epistemological apparatus and "coherent" methodology within the discipline allowing capturing and describing aesthetic phenomena in usual rational ways. In particular, Kant, a classic of German philosophy, wrote the following on the key issue of aesthetics: " $<\ldots>$ The judgement of taste is not a cognitive judgment, thus it is not a logical, but an aesthetic judgment, which refers to the judgment, whose determining principle can be only subjective. However, every relation of representations, even the relation of sensations can be objective (and then it is real in an empirical representation) $<\ldots>$. The data in the judgment of a representation can be empirical (and thus aesthetic); the judgment made through is logical, only if these representations are related in the judgment with the object. On the contrary, even if these representations are rational, but in the judgment are related only to the subject (to its feeling), then such a judgment is always an aesthetic judgment» [Kant, 1994: 70-71]. In fact, Kant assigns a particular priori principle that differs from a logical judgment to an aesthetic judgment that is the absence of a cognitive judgment since its foundation is subjective.

On top of a brief historical-philosophical overview of the aesthetic problems, we give a few opinions of modern domestic philosophers about aesthesis and aesthetics that will help us to expand and maintain the topologic of the aesthetic in the context of our study: "Aesthesis as a condition of an excessive act of "the stiffness of gripes", with respect to its dynamic and topological distinction, contemplative-reflective and projective-active features", as V. Kruglov writes [Kruglov, 2009: 195]. Aesthesis as "sensuous being in the beauty of existence" is defined by A. Kazin [Kazin, 2010: 126]. S. Dzikevich offers to consider "nonverbal intellectual knowledge and non-verbal intellectual communication» to be the subject of aesthetics [Dzikevich, 2004: 17].

\section{Discussion}

So, "aesthesis" as the sphere of the sensuousemotional and contemplative-reflective, distinct 
from the logic and mind-rational sphere ("noesis") is the subject of aesthetics. Consequently, fetishism can be comprehended and secured within aesthetic theory as there is no convincing concept that helps to explain and also "to protect" fetishism from other disciplinary claims both in natural science (neurophysiology, psychology) and in the area of historical-religious discourse (theology). Simply put, after identifying and describing the types of fetishism (religious, psychological, commodity), the researchers did not answer the main question: what is, actually, fetishism? The origin of fetishism, highlighting and revealing itself in different cultural sections, indicates the "vertical" existential presence in the world, whose "redundancy" "spreads" filling potentially all the known material (materialized) space of the anthropological world with itself. Don't you think that the reason why the motif of an aesthetic dominant of fetish is so insistent, falls beyond the scope of religious and psychological discourses, is the direct relationship of aesthesis (gnosis) and fetish (praxis)?

In light of this questioning, the key to opening the proposed correlate could lie in consideration of the basic positions of the modern theory of aesthetization (Ästhetisierung). The author of the theory is Walter Benjamin, an aesthetician and art theorist. Speaking of aestheticization as a process of social interaction through some ritual and traditional forms (as blockers of reality) rooted in the culture, he dresses aestheticization in a negative rag, woven of suggestive and manipulative tissue for which he picks up an ambiguous term "aura". "This aura can be defined as a unique feeling of the horizon no matter how close this thing may be. Glancing at the line of a mountain range on the horizon or a branch under which you have a rest during the summer afternoon means breathing the aura of those mountains, of that branch. $<\ldots>$ Namely, a longing to "hasten" things in a spatial and human respect is as characteristic of modern mass, as the trend of overcoming the uniqueness of every datum through the adoption of its reproduction. Every day an irresistible need to master a subject in close vicinity through its image, or more precisely, through its display, reproduction, appears» [Benjamin, 1996: 25]. Another term can be an analogue of "aura", that is "an aesthetic mask" which indicates, according to the modern researcher N. Saenko, "a sacred body of sense" [Saenko, 2011: 94].

Please note that the idea of "display" and "reproduction" itself is not new. So, even Plato outlined the ontological range of authentic and simulative images. In fact, W. Benjamin thinks about the same problem - the problem of simulativity as replicated repeatability (technicism) - seeing the loss of ontological authenticity, substituted (embodied) by the material form, in it. (One interesting case mentioned in one of the works of Michel Foucault about the surprise of aborigines of one tribe at the first meeting with a material replicability that was a book can be given as an illustrative example). As a result, Benjamin comes to the following conclusion: aesthetization is the blocking of a reflective capacity of a subject, and what is the basis for the possibility of manipulation by masses by means of popular artifacts. (By the way, the similar judgments can be found in the concept of "the bewitched world" of M. Maffesoli).

But there is another interpretation of the process of aesthetization - namely, the view of G. Schulze, a modern German sociologist, according to whom, on the contrary, anesthetization is accompanied just with increasing reflexivity. Consequently, the wider the range of possibilities, which are not limited at all, is, the more the decision, which is forced to become reflexive, is vested in the subject itself. For this it needs competences that will allow it to take a distanced position in relation to the circumstances. "A 
mature person, who is looking for experiences, is well aware of the fact that music is not just sound waves. And that is why the situation predicted by Walter Benjamin did not happen: art has not lost its aura. So many people have never gone to museums before. So when they see a painting by Vincent van Gogh in the original, they feel something different from what they feel when they leaf an album with reproductions. The popularity of exhibitions and concerts indicates that people are increasingly looking for an aura of a unique experience", Schulze says [Schulze, 2011].

We shall clarify that the German sociologist talks about the formation of a new kind of societya "society of experiences" - in which the way of a beautiful life as a way (experience) to overcome something is elected as a key project (a vivid example is the style of "glamor"). Consequently, the modern society is the society of aesthesis era that is a cyclical process of reproduction and consumption of objects of experience. The need for a permanent experience of aesthesis is a specific challenge to modern culture, forced to respond to a massive demand through appropriate proposals (aesthesis proposals). The fabrication of impressions (their "reproducibility" by G. Schulze) becomes the guiding principle of the market: the impression "comes fitted" with the main item. Therefore it is not difficult to trace the following dynamics of experiences: horror movies are getting "more horrific", blockbusters "more entertaining"; fiction - thematically and structurally more honest and sophisticated; cars more refined and "aggressive"; fashion - more shocking and so on, from toys for children up to adult entertainment.

Focusing the views of $\mathrm{W}$. Benjamin and G. Schulze at one point, it is necessary to make the following observation. Despite the apparent difference of concepts, both scientists agree on one thing: "the blocking of reality" (by
Benjamin) and "the strengthening of reflexivity" (by Schulze) are the two poles of a single vector (aestheticization) that essentially does not matter, like two different reactions of two viewers to the same event do not matter too (for example, one of them experiences elation listening to the final of "Ninth Symphony" by Beethoven, while the other feels confusion). In other words, both experiences are an indication to aesthetic coexistence (evidence of co-existence).

Comparing the thought of Schulze about the role of the subject in a society of experiences (where the process of aestheticization is characterized by the increased reflexivity of the subject!) with the conclusion of Kant on the subjective basis of an aesthetic judgment, we get the denominator of community of aesthetic nature of fetish and aesthetization manifested not so much in the obvious similarity of attributes as in the same degree of perception of these phenomena by the subject. In order to give a greater illustrative example, we will mention a very timely idea of the Russian philosopher G. Shpet about the appearance of an aesthetic fact in life: "They want something that can not be turns into something that exists, that can not but exist. But this is a return to the unadorned, nature, animal life that can be beautiful only in some rare cases of the nature's play and disgrace. There are almost always a handful of potsherds instead of gold here» [Shpet, 2010].

So how are aesthesis (gnosis, the strength of experience, a motivating emotional impulse) and fetish (praxis, the environment of the objectification of aesthesis) related? How obvious is this relationship? Can we talk about their identification, or should we resolutely deny even their attributive generality?

To clarify the correlate of aesthesis and fetish we allow ourselves to resort to the following conceptual pair: alpha-strat / betastrat. Aesthesis understood as alpha-strat is 
the totality of inherited-present-repeatedhomostructural internal (deep) properties of an object; consequently, fetish being correlated with beta-strat is a totality of individual (external) properties and characteristics of development of alpha-strat (manifestation of a power form of aesthesis). If anything, it can be understood as a kind of attempt of praxis aestheticization, "burying" of spirit, retention of aesthesis, directing it into the mainstream of practical definition. Let us explain: at the attempt to describe the implicit mechanics of, say, religious fetishism, religious modes will be revealed more or less clearly. But as soon as we touch the inner core - alpha-strat, we will be forced to admit the existence of the same infinitely repeating pattern (aesthesis), which, quite obviously, has no direct relationship (at least in this context) with the nature of the religious beginning. At the same time, fetish is easily found in a wide variety of toposes of culture by phenotypic features.

Therefore, the problem of identification of the aesthetic nature in fetish is largely in an initial focus on rational understanding of aesthetic experience by the subject, in other words, the rationalization of the "transition" from the external orientation (beta-strat) to the internal (alphastrat). (However, subjective-rational "decoding" while "reading" this or that fetish is ultimately impossible). But (!) it is a rational inexpressiveness of the latter that should be attributed to the key characteristics of the aesthetic. Moreover, the totality of evidences (for example, a toponymic method) only impede a rational focus, without telling anything essential, thereby foredooming a researcher to an endless wandering around the far radial catacombs of the labyrinth in which "a rational transition", in fact, is reduced to banal descriptiveness diagnosing the phenotypic state of alpha-strat recognized by the subject. Here is an example: Fandorin, the protagonist of the novel "All the world's a stage" by B. Akunin, is a rationalist and deduct. In the novel he tries to make sense of his sudden impression: "Fandorin would have found it difficult to explain exactly how to decipher the thought that made him hold tight on the armchair handrails - because he had an uncontrollable desire to stand up and come closer to stare at her eagerly and intently. What is so special about her, he asked himself, as usual trying to rationalize the irrational. Where from is a sense of unprecedented, magnetizing beauty? (emphasis added). He tried to judge impartially. Indeed, strictly speaking, she is not a beauty. Her features are perhaps too small. Her type is not classical: angular figure, sharp shoulders, a thin-lipped mouth that is too wide, a nose with a small hump. But all these irregularities did not weaken, but only reinforced the impression of a miracle»[Akunin, 2013: 59]. It is obvious: the descriptiveness (beta-stratability) does not allow us to distil anything intrinsic-informative from the direct aesthetic experience (alpha-stratability). At the same time, this antinomy does not prevent the subject from feeling the alpha-stratic (trying to identify, explain, give substance to) bases of betastrat. For example, this can explain the existence of fetish as beta-strat in the environment of religious existence, when its alpha-stratic level is filled (remember the reflexivity of the subject!) with eligious and spiritual (mystical) content. The same object-fetish in a different environment (including even the change of the environment of religious existence) can easily get filled with another alpha-stratic content.

Even if we "explain" fetish in all its possible relations, even providing the conscious fetishization of a thing, it will also be impossible to identify the primary motivating impulse (alias aesthesis). Like it is impossible - in the same conditions - to explain the occurrence of infant attraction (a psycho-emotional tropos of fetish) to some people, and a sense of hostility to others; fetish, as noted above, can only be recognized 
and admitted (hair color, the smell of leather, snow, jazz, etc). The analysis of the mechanisms of existence of fetishism rooted in the everyday life, for example, favourite clothing, collecting, superstitious charms, is nothing more than the evidence of "uncharmability" (M. Weber) of the modern world, the world that is like "the wind of another parallel" (A. Bashlachev), touching with which man of the third millennium reproduces all the same ritual matrix of conduct, mastered by a homo that is infinitely distant from our times, wanting to be different - intelligent, however remaining a hostage and novice of the mystic code of aesthesis. C. Jung accurately marks: "If man were a rational animal, then these calls to mind would be appropriate. But man by nature is not like that - at least just as much as he is not wise» [Jung, 1941].

Therefore, the imposition of hasty assessments of fetishism - whether it is a theoretical reproach about the diminishing of religious consciousness, or diagnosis of a mental disorder of a sexual nature - is, on the one hand, the evidence of a position of research self-isolation, and, on the other hand, it is an indication to the presence of a problem field on the anthropocultural vector of history, and hence its further development demands a certain degree of delicacy and consistency.

\section{Resume}

Summing up the study of the phenomenon of fetishism, we offer the following definitions:

Fetish is an aesthetic phenomenon; a form of spiritual or material reality, which has a subjective value color and endowed with certain spiritual powers. Fetish has the ability to embed organically in any sociocultural context.

Fetishismis a form of aesthetic consciousness, expressed in subjective sensuous-emotional experience of fetish and final conclusions:

- Philosophical reflection defines fetishism as "religion of sensuous lusts", suggesting the aesthetic nature of the phenomenon;

- The analysis of the theory of aestheticization, describing the process of interaction of the subject with "the society of impressions" ("blocking of reality" (by Benjamin) and "the strengthening of reflexivity" (by Schulze), allows us to conclude that aesthesis is the evidence of co-existence, the dominant presence of which is stable and does not depend on dynamic changes in the historical and sociocultural paradigm;

- The relationship of aesthesis and fetish is revealed through the conceptual pair of its alpha-strat / beta strat: aesthesis as alpha-strat is the totality of inherited-present-repeatedhomostructural internal properties of the object; fetish as beta-strat is the totality of individual (external) properties and characteristics of development of alpha-strat (an imperative form of aesthesis);

- Beta-strat does not disclose the intrinsicinformative nature of alpha-strat, but beta-strat in the conditions of different environment of existence is variable (in religious, psychoemotional and everyday spheres), and may acquire another intrinsic-informative alphastratic content.

\section{References}

Akunin B. Ves $\square$ mir teatr [All the world's a stage]. Moscow, Zaharov, 2013. 480 p.

Baumgarten A.G. Istoriia estetiki. Pamiatniki mirovoi esteticheskoi mysli [The history of aesthetics. Monuments of the world aesthetic thought], V. 2. Moscow, Iskusstvo, 1964. 835 p.

Benjamin W. Proizvedenie iskusstva v epokhu ego tekhnicheskoi vosproizvodimosti [A work of art during an era of its technical reproducibility]. Moscow, Medium, 1996. 240 p. 
Dzikevich S.A. Estetika reklamy: Esteticheskaia struktura reklamnoi kommunikatsii [Advertizing aesthetics: aesthetic structure of advertizing communication]. Moscow, Gardariki, 2004. 231 p.

Eliade M. Ioga: bessmertie i svoboda [Yoga: immortality and freedom]. Sankt-Petersburg, Lan $\square$ , 1999. p. 446.

Jung C.G. Psikhoterapiia i mirivozzrenie [Psychotherapy and worldview] Perevod s nem. L. Rutkevicha [Translated by L. Rutkevich], 2014. Available at: http://www.psycho.org.ua/pap88.htm (accessed 21 August 2014).

Kant I. Kritika sposobnosti suzhdenia [Criticism of an ability to judge]. Moscow, Iskusstvo, 1994. $367 \mathrm{p}$.

Kruglov V.L. Chelovek epokhi «modern»: antropologiia kultury kak kritika detsentrirovannogo razuma [Man of the era of "modern": anthropology of culture as criticism of decentered mind]. Krasnoyarsk, KGAMiT, 2009. 241 p.

Kazin A.L. Iskusstvo russkoifilosofii [Art of the Russian philosophy]. Vestnik Russkoi khristianskoi gumanitarnoi akademii [Bulletin of Russian Christian Humanitarian Academy], 11 (3), 2010. p.126135.

Saenko M.F. Struktura, destruktsiia i rekonstruktsiia znaka vactual'nom iskusstve, ili esteticheskie maski pustoty [Structure, destruction and reconstruction of a sign in actual art, or aesthetic masks of emptiness]. Voprosy kul $\square$ turologii [Culturology issues], 11, 2011. p. 94-98.

Shpet G.G. Esteticheskie fragmenty: svoevremennye napominaniia. Struktura slova in usum aestheticae [Aesthetic fragments: timely reminders. Structure of the word in usum aestheticae]. Moscow, Librokom, 2010. Available at: http://www.magister.msk.ru/library/philos/shpet01.htm (accessed 03 September 2014).

Schulze G. Proizvodiat vpechatleniia [Making impressions]. Available at: http://esquire.ru/events (accessed 12 May 2014).

\section{Эстетические тропосы фетишизма}

Ю.В. Соболев

Красноярский государственный институт искусств Россия, 660049, Красноярск, ул. Ленина, 22

Рассматриваются эстетические тропосы. Обращаясь $к$ фундаментальным работам, посвященным фетишизму и эстетике (А. Баумгартен, К. Маркс, В. Беньямин, Г. Шульие и др.), выявляется характерная эстетическая природа фетишизма. Обобщая различные позиции, выдвигается и обосновывается гипотеза об эстетической протоприроде фетишизма.

Ключевые слова: фетишизм, эстетика, эстезис, эстетизаиия, религиозный феномен, альфаcтрат, бета-страт.

Научная специальность: 24.00.00 - культурология. 